\title{
Chemical characterisation of iron in dust and biomass burning aerosols during AMMA-SOP0/DABEX: implication for iron solubility
}

\author{
R. Paris ${ }^{1}$, K. V. Desboeufs ${ }^{1}$, P. Formenti ${ }^{1}$, S. Nava $^{2}$, and C. Chou ${ }^{3}$ \\ ${ }^{1}$ LISA, Universités Paris 12 et Paris 7, CNRS, UMR 7583, Créteil, France \\ ${ }^{2}$ National Institute of Nuclear Physics, Florence, Italy \\ ${ }^{3} \mathrm{ETH}$, Institut für Atmosphäre und Klima, Zürich, Switzerland
}

Received: 12 October 2009 - Published in Atmos. Chem. Phys. Discuss.: 25 November 2009

Revised: 17 April 2010 - Accepted: 22 April 2010 - Published: 6 May 2010

\begin{abstract}
The chemical composition and the soluble fraction were determined in aerosol samples collected during flights of AMMA-SOP0/DABEX campaign, which were conducted in the West African Sahel during dry season (2006). Two aerosol types are encountered in this period: dust particles (DUST) and biomass burning aerosol (BB). Chemical analysis and microscope observations showed that the iron (Fe) found in BB samples mainly originates from dust particles mostly internally mixed in the biomass burning layer. Chemical analyses of samples showed that the Fe solubility is lower in African dust samples than in biomass burning aerosols. Our data provide a first idea of the variability of iron dust solubility in the source region $(0.1 \%$ and $3.4 \%)$. We found a relationship between iron solubility/clay content/source which partly confirms that the variability of iron solubility in this source region is related to the character and origin of the aerosols themselves. In the biomass burning samples, no relationship were found between $\mathrm{Fe}$ solubility and either the concentrations of acidic species $\left(\mathrm{SO}_{4}^{2-}, \mathrm{NO}_{3}^{-}\right.$ or oxalate) or the content of carbon (TC, OC, BC). Therefore, we were unable to determine what processes are involved in this increase of iron solubility. In terms of supply of soluble Fe to oceanic ecosystems on a global scale, the higher solubility observed for Fe in biomass burning could imply an indirect source of $\mathrm{Fe}$ to marine ecosystems. But these aerosols are probably not significant because the Sahara is easily the dominant source of Fe to the Atlantic Ocean.
\end{abstract}

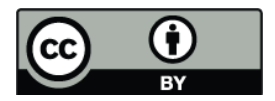

Correspondence to: R. Paris (rodolphe.paris@lisa.univ-paris12.fr)

\section{Introduction}

The North Atlantic Ocean is under the influence of mineral dust plumes transported from West Africa. Consequently, African dust is the major source of iron to this open ocean region (Sarthou et al., 2003). Its deposition may influence the rate of nitrogen fixation by microorganisms, and subsequently the global carbon cycle (Mills et al., 2004; Moore et al., 2002). Beside dust emission, the African continent is affected by strong biomass burning events all year round, due to widespread savannah fires and agricultural fires. The event of biomass burning in Africa follows a well determined seasonal cycle related to the seasonal shift in the InterTropical Convergence Zone (ITCZ). Thus, maximum emissions of anthropogenic biomass burning aerosol from the south regions of northern Africa occur during the dry season (December/January/February), with very few emissions occurring during August/September/November (Nwofor et al., 2007).

On the global scale, the major source of primary carbonaceous aerosols is biomass burning, due to forest fires and to the widespread use of fuel for home-heating and cooking (Ito and Penner, 2005). Recently, Luo et al., (2008) suggested that combustion iron (industry, biofuels and biomass burning) having a higher bioavailability, it could represent $50 \%$ of the global iron deposition budget. The work of Guieu et al. (2005), based on experimental iron solubility measurement, emphasizes that biomass burning may be an important input of iron to the Mediterranean Sea relative to Saharan dust input. Because of the specific weather conditions and the greater diversity of vegetation types burned in forest fires, regional differences in biomass burning aerosol

Published by Copernicus Publications on behalf of the European Geosciences Union. 
compositions are expected. This implies that more work should be done to refine the assessment of the solubility of iron issued from biomass burning sources. In this context, the international field campaign AMMA-DABEX (Analysis Multidisciplinary of African Monsoon-Dust and Biomass burning Experiment), conducted in Sahelian regions during the January-February dry season (2006) offered an excellent framework to study the solubility of iron from biomass burning and from mineral dust. Indeed, DABEX Special Observation Periods covered almost exclusively the dry season over Niamey (Niger), a period dominated by minerals dust and biomass burning particles mixing events. In this paper, we present an estimation of African dust and biomass burning aerosols contribution to the supply of soluble iron to the ocean by atmospheric deposition. In order to do so, we measured the water soluble fraction on aerosol samples collected onboard the aircraft FAAM Bae-146.

\section{Material and method}

\subsection{Sampling}

Instruments and samplers were operated onboard the UK Facility for Airborne Atmospheric Research (FAAM) BAe-146 research aircraft (http://www.faam.ac.uk/). The region of operation of the aircraft during the AMMA-SOP0/DABEX experiments and the full description of the aircraft and onboard instrumentation are presented in Haywood et al. (2008). The aerosol sampling system for filter collection consists of two stacked-filter units (SFUs) mounted in parallel. Samples were collected only during horizontal flight legs lasting not less than 20-30 min. in order to guarantee sufficient loading of the filter samples. One SFU was used for the measure of water-soluble ions and major, minor, and trace elements. In this case, SFU consisted of a Nuclepore filter of nominal pore size $0.4 \mu \mathrm{m}, 90 \mathrm{~mm}$. The second SFU was used for the measure of carbonaceous aerosols. In this case, the sampling medium consisted of one Whatman QMA quartz filter, $47 \mathrm{~mm}$. Quartz filters were pre-baked at $600^{\circ} \mathrm{C}$ for approximately $12 \mathrm{~h}$ to eliminate organic impurities. 57 filter samples have been collected during the 13 research flights of the BAe-146, performed from Niamey, Niger during AMMASOP0/DABEX. In parallel with aerosols sampling, we estimated the contamination of the method with the use of "blank filters". All details of the sampling method are described in Formenti et al., (2008). The identification and the details of the operational sampling conditions for the studied filters are summarized in Table 1.

\subsection{Chemical composition}

Total elemental concentrations for elements ranging from $\mathrm{Na}$ to $\mathrm{Pb}$ (Note: $\mathrm{TFe}$ for Total elemental $\mathrm{Fe}$ ), for all collected samples, were measured by Particle-Induced X-ray Emission (PIXE) at the 3 MV Tandetron accelerator of the Labec laboratory (Formenti et al., 2008), with the external beam set-up described in Calzolai et al. (2006). PIXE spectra were fitted using the GUPIX code and elemental concentrations were obtained via a calibration curve from a set of thin standards (Chiari et al., 2005); it should be noted that the concentrations of light elements, such as Al, may be somewhat underestimated due to X-rays self-absorption inside aerosol particles (Marino et al., 2008). A two-step thermal method was applied for the separation and the analysis of black and organic carbon aerosol contents (BC and OC, respectively). The protocol (Cachier et al., 1989) consists firstly in an acidic step to remove carbonates; secondly, in a thermal pre-treatment under pure $\mathrm{O}_{2}$ and during $2 \mathrm{~h}$; and finally in the coulometric analysis (Ströhlein COULOMAT 702C) of carbon.

\subsection{Water soluble fraction}

Sample handling was performed in an ultra clean laboratory (class $<1000$ ) on ultra clean laminar flow benches (Class $<10$ ). Dissolution experiments, to measure the water-soluble fraction of collected aerosols, have been carried on 31 filters (over 57 collected): 13 DUST and 18 BB samples (13 $\mathrm{BB} 1$ and 5 BB2) (Table 1). To prepare the sample solution, one quarter of each SFU filters and blank filters was extracted using $100 \mathrm{~mL}$ water (of $18.2 \mathrm{M} \Omega \mathrm{cm}^{-1}$ resistance) during $30 \mathrm{~min}$ of ultrasonic agitation (Guinot et al., 2006, Karthikeyan et al., 2006, Chang et al., 2005, Wang et al., 2005). Recent works displays that ultrasonication could produce $\mathrm{H}_{2} \mathrm{O}_{2}$ by acoustic cavitations (Kanthale et al., 2008). $\mathrm{H}_{2} \mathrm{O}_{2}$ could induce the oxidation of soluble $\mathrm{Fe}(\mathrm{II})$ into insoluble Fe(III) (Zhu et al., 1993) or inverse (Pehkonen et al., 1993). Consequently, the ultrasonification could impact on the values obtained for iron solubility.

The solution was filtered on a $0.2 \mu \mathrm{m}$ Nucleopore polycarbonate filter (Whatman). Inorganic and organic anions species $\left(\mathrm{Cl}^{-}, \mathrm{Br}^{-}, \mathrm{NO}_{2}^{-}, \mathrm{NO}_{3}^{-}, \mathrm{SO}_{3}^{2-}, \mathrm{SO}_{4}^{2-}\right.$, acetate, formate, propionate, butyrate, MSA-, pyruvate, valerate, and oxalate) were quantified by ion chromatography. Ion chromatography (IC) analysis have been carried out with a Dionex 4500i device, equipped with an AS11-HC column associated with an AG11 pre-column. For simultaneous separation of inorganic and short-chain organic anions, gradient elution by $1-66 \mathrm{mM} \mathrm{NaOH}(1.5 \mathrm{~mL} / \mathrm{min})$ was used. Dissolved iron concentration (DFe) was analysed by GFAAS (ATI-Unicam 929) (Sofikitis et al., 2004). Multi-elementary analysis of the dissolved phase was made by ICP-AES (PE Optima 3000) (Desboeufs et al., 2003).

\section{Results and discussion}

\subsection{Characterisation of particulate iron}

During AMMA-SOP0/DABEX campaign, mineral dust was generally observed at low altitudes (up to approximately 
Table 1. Sample Identification and Main Operational Details for the Sampled Filter (for lon/lat: start/end sampling) (Note: PIXE measurement, Al, Ca, K, Mg, S, Si, and Fe in $\mu \mathrm{g} \mathrm{m}^{-3}$ ). Red: Samples used for the determination of the WSF.

\begin{tabular}{|c|c|c|c|c|c|c|c|c|c|c|c|c|c|}
\hline DATE & SAMPLE ID & LOCATION & Lat $\left({ }^{\circ}, \operatorname{dec}^{\circ}\right)$ & $\operatorname{Lon}\left({ }^{\circ}, \operatorname{dec}^{\circ}\right)$ & Altitude $(\mathrm{km})$ & Group & $\mathrm{Al}$ & $\mathrm{Ca}$ & $\mathrm{K}$ & $\mathrm{Mg}$ & $\mathrm{S}$ & $\mathrm{Si}$ & $\mathrm{Fe}$ \\
\hline 16 Jan 2006 & $\mathrm{~B} 157 \mathrm{~N} 1$ & Niger/Nigeria & $12.6 / 11.3$ & $3.9 / 4.3$ & 2.4 & BB1 & 0.8 & 1.3 & 0.8 & 0.6 & 1.1 & 3.8 & 0.5 \\
\hline 16 Jan 2006 & $\mathrm{~B} 157 \mathrm{~N} 2$ & Niger/Nigeria & $11.1 / 9.9$ & $4.3 / 4.3$ & 2.0 & $\mathrm{BB} 1$ & 7.0 & 2.9 & 2.1 & $<\mathrm{DL}$ & 1.1 & 8.6 & 3.2 \\
\hline 16 Jan 2006 & B157N3 & Niger/Nigeria & $10.4 / 11.5$ & $4.3 / 4.1$ & $1.2-0.7$ & BB2 & 18.8 & 15.8 & 6.4 & 3.4 & 1.7 & 63.0 & 11.6 \\
\hline 16 Jan 2006 & B157N4 & Niger/Nigeria & $11.7 / 13.5$ & $2.4 / 3.2$ & 0.5 & Dust & 11.8 & 7.3 & 2.6 & 1.5 & 0.9 & 35.4 & 7.4 \\
\hline 16 Jan 2006 & B157N5 & Niger/Nigeria & $13.5 / 13.6$ & $2.4 / 3.2$ & 2.7 & BB2 & 1.1 & $<\mathrm{DL}$ & $<\mathrm{DL}$ & $<\mathrm{DL}$ & 1.0 & 3.2 & 0.7 \\
\hline 17 Jan 2006 & B158N1 & Niger/Nigeria & $12.3 / 12.1$ & $3.8 / 4.2$ & 3.3 & BB2 & 2.8 & 0.2 & $<\mathrm{DL}$ & $<\mathrm{DL}$ & 2.1 & 9.1 & 2.3 \\
\hline 17 Jan 2006 & B158N2 & Niger/Nigeria & $11.8 / 10.3$ & $4.3 / 4.3$ & $1.7-2.1$ & BB1 & 10.3 & 7.9 & 4.4 & 1.8 & 1.1 & 35.8 & 6.7 \\
\hline 17 Jan 2006 & B158N3 & Niger/Nigeria & $9.8 / 8.4$ & $4.3 / 4.3$ & $0.8-1.6$ & BB1 & 15.2 & 10.7 & 8.0 & 2.5 & 2.4 & 53.6 & 10.0 \\
\hline 17 Jan 2006 & B158N4 & Niger/Nigeria & $8.3 / 8.3$ & $4.3 / 4.3$ & $2-3$ & $\mathrm{BB} 1$ & 12.7 & 7.2 & 6.9 & 1.9 & 2.2 & 40.8 & 7.9 \\
\hline 17 Jan 2006 & B158N5 & Niger/Nigeria & $11.0 / 12.0$ & $4.3 / 4.3$ & 0.6 & BB1 & 16.5 & 12.0 & 8.0 & 3.2 & 2.3 & 53.9 & 10.5 \\
\hline 17 Jan 2006 & B158N6 & Niger/Nigeria & $12.2 / 12.6$ & $4.1 / 3.6$ & $1.6-2$ & BB1 & 3.1 & 1.2 & 1.1 & $<\mathrm{DL}$ & 0.4 & 5.1 & 1.8 \\
\hline 19 Jan 2006 & B159N1 & Niger/Benin & $13.6 / 13.4$ & $2.5 / 1.9$ & 3.3 & BB2 & 6.4 & $<\mathrm{DL}$ & 1.0 & $<\mathrm{DL}$ & 1.2 & 19.6 & 4.3 \\
\hline 19 Jan 2006 & B159N2 & Niger/Benin & $13.4 / 13.5$ & $1.8 / 2.6$ & 2.7 & BB1 & 9.4 & 3.3 & 5.1 & 1.7 & 2.2 & 31.2 & 6.3 \\
\hline 19 Jan 2006 & B159N3 & Niger/Benin & $13.6 / 13.4$ & $2.7 / 1.9$ & 1.7 & BB1 & 8.4 & 3.2 & 3.7 & 1.5 & 1.7 & 27.3 & 5.4 \\
\hline 19 Jan 2006 & B159N4 & Niger/Benin & $13.4 / 13.6$ & $2.1 / 2.7$ & 0.15 & Dust & 21.8 & 10.2 & 3.7 & 2.7 & 1.1 & 56.4 & 13.0 \\
\hline 19 Jan 2006 & B159N5 & Niger/Benin & $12.9 / 11.2$ & $2.5 / 2.6$ & profile & BB2 & 13.9 & 6.4 & 3.6 & 1.8 & 0.9 & 35.3 & 8.3 \\
\hline 19 Jan 2006 & B159N6 & Niger/Benin & $11.0 / 9.8$ & $2.6 / 1.6$ & 0.15 & BB2 & 14.3 & 7.9 & 3.6 & 0.8 & 0.5 & 21.0 & 9.2 \\
\hline 19 Jan 2006 & B159N7 & Niger/Benin & $9.8 / 12.2$ & $1.6 / 2.4$ & $1.7-2.3$ & BB1 & 6.9 & 3.2 & 4.1 & 0.9 & 1.8 & 21.7 & 4.3 \\
\hline 19 Jan 2006 & B159N8 & Niger/Benin & $12.4 / 13.2$ & $2.3 / 2.1$ & 2.0 & BB 1 & 4.9 & 1.3 & 3.0 & 1.4 & 1.3 & 17.0 & 3.5 \\
\hline 21 Jan 2006 & $\mathrm{~B} 160 \mathrm{~N} 1$ & North Niger & $13.7 / 15.0$ & $2.6 / 4.3$ & $3-3.3$ & BB1 & 5.8 & 2.2 & 1.5 & 1.0 & 0.9 & 11.4 & 2.6 \\
\hline 21 Jan 2006 & $\mathrm{~B} 160 \mathrm{~N} 2$ & North Niger & $15.1 / 15.9$ & $4.4 / 4.9$ & 2.5 & Dust & 3.5 & 1.6 & 1.0 & 0.6 & 0.8 & 9.6 & 2.3 \\
\hline 21 Jan 2006 & B160N3 & North Niger & $16.1 / 18.5$ & $4.9 / 6.9$ & $1.7-1.0$ & Dust & 29.4 & 15.2 & 5.7 & 3.1 & 0.8 & 83.0 & 18.2 \\
\hline 21 Jan 2006 & $\mathrm{~B} 160 \mathrm{~N} 4$ & North Niger & $18.4 / 18.2$ & $6.9 / 5.9$ & 1.2 & Dust & 8.5 & 3.3 & 0.2 & 1.2 & 0.4 & 27.0 & 5.4 \\
\hline 21 Jan 2006 & B160N6 & North Niger & $14.6 / 14.0$ & $3.6 / 2.8$ & 2.7 & Dust & 3.5 & 2.3 & 1.0 & $<\mathrm{DL}$ & 0.7 & 10.1 & 2.5 \\
\hline 23 Jan 2006 & $\mathrm{~B} 161 \mathrm{~N} 1$ & North Niger & $14.2 / 15.1$ & $3.2 / 4.5$ & 4.0 & BB 1 & 2.5 & 0.6 & 1.2 & $<\mathrm{DL}$ & 1.2 & 7.0 & 2.0 \\
\hline 23 Jan 2006 & $\mathrm{~B} 161 \mathrm{~N} 2$ & North Niger & $15.2 / 16.1$ & $4.6 / 5.8$ & 3.3 & BB1 & 1.7 & 0.1 & 0.9 & $<\mathrm{DL}$ & 1.0 & 5.0 & 1.6 \\
\hline 23 Jan 2006 & $\mathrm{~B} 161 \mathrm{~N} 3$ & North Niger & $16.4 / 17.2$ & $6.1 / 7.1$ & 1.0 & Dust & 47.7 & 23.2 & 9.1 & 5.3 & 1.2 & 123.1 & 27.7 \\
\hline 23 Jan 2006 & B161N5 & North Niger & $17.3 / 16.7$ & $7.4 / 6.6$ & 1.0 & Dust & 100.3 & 42.3 & 17.5 & 10.6 & 4.8 & 229.9 & 58.1 \\
\hline 23 Jan 2006 & B161N6 & North Niger & $16.3 / 13.9$ & $6.0 / 2.9$ & $0.15-1.0$ & Dust & 33.0 & 15.8 & 5.7 & 3.5 & 1.0 & 88.3 & 18.4 \\
\hline 24 Jan 2006 & $\mathrm{~B} 162 \mathrm{~N} 1$ & Niger/Nigeria & $12.3 / 10.6$ & $2.4 / 2.9$ & 3.7 & BB1 & 1.7 & 0.0 & 0.8 & $<\mathrm{DL}$ & 1.1 & 4.2 & 1.1 \\
\hline 24 Jan 2006 & $\mathrm{~B} 162 \mathrm{~N} 2$ & Niger/Nigeria & $10.4 / 9.8$ & $3.1 / 3.5$ & 3.7 & BB2 & 1.5 & $<\mathrm{DL}$ & 0.1 & $<\mathrm{DL}$ & 1.5 & 2.8 & 1.0 \\
\hline 24 Jan 2006 & $\mathrm{~B} 162 \mathrm{~N} 3$ & Niger/Nigeria & $11.2 / 11.2$ & $4.0 / 3.5$ & 0.7 & BB2 & 42.9 & 15.8 & 8.5 & 4.8 & 0.7 & 111.5 & 24.3 \\
\hline 24 Jan 2006 & B162N4 & Niger/Nigeria & $11.1 / 11.2$ & $3.5 / 3.5$ & $0.7-0.9$ & BB2 & 23.6 & 11.4 & 6.0 & 2.7 & 0.8 & 63.3 & 13.5 \\
\hline 26 Jan 2006 & $\mathrm{~B} 163 \mathrm{~N} 1$ & Around Niamey & $13.5 / 13.6$ & $2.3 / 2.7$ & $2.3-3.8$ & $\mathrm{BB} 1$ & 3.9 & 1.1 & 1.7 & $<\mathrm{DL}$ & 1.2 & 10.5 & 2.3 \\
\hline 26 Jan 2006 & B163N2 & Around Niamey & $13.7 / 13.3$ & $2.8 / 1.8$ & $0.6-1.2$ & Dust & 33.3 & 12.9 & 5.5 & 3.2 & 1.6 & 76.8 & 18.7 \\
\hline 26 Jan 2006 & B163N4 & Around Niamey & $13.6 / 13.4$ & $2.7 / 1.9$ & $2.1-3.5$ & BB1 & 3.7 & 1.3 & 1.5 & 0.5 & 1.3 & 10.0 & 2.4 \\
\hline 26 Jan 2006 & B163N5 & Around Niamey & $13.6 / 13.4$ & $2.9 / 1.9$ & 0.15 & Dust & 33.2 & 12.4 & 5.5 & 3.7 & 2.1 & 76.8 & 19.1 \\
\hline 29 Jan 2006 & B164N1 & Around Niamey & $13.6 / 13.5$ & $2.3 / 2.2$ & 3.5 & BB2 & 3.7 & 0.9 & 0.5 & 1.0 & 1.0 & 9.9 & 2.4 \\
\hline 29 Jan 2006 & $\mathrm{~B} 164 \mathrm{~N} 3$ & Around Niamey & $13.5 / 13.5$ & $2.3 / 2.2$ & 1.2 & Dust & 13.9 & 6.6 & 2.8 & 1.8 & 1.0 & 35.6 & 8.3 \\
\hline 29 Jan 2006 & B164N4 & Around Niamey & $13.5 / 13.5$ & $2.3 / 2.2$ & 0.6 & Dust & 15.3 & 7.6 & 3.0 & 1.8 & 0.6 & 40.2 & 9.1 \\
\hline 30 Jan 2006 & $\mathrm{~B} 165 \mathrm{~N} 1$ & North Niger & $13.9 / 14.6$ & $3.2 / 3.9$ & 3.3 & BB2 & 3.8 & 0.2 & 0.8 & $<\mathrm{DL}$ & 1.6 & 4.1 & 2.4 \\
\hline 30 Jan 2006 & $\mathrm{~B} 165 \mathrm{~N} 2$ & North Niger & $14.9 / 17.4$ & $4.3 / 7.4$ & $1.0-1.2$ & Dust & 10.5 & 4.3 & 2.1 & 1.3 & 0.7 & 27.4 & 6.4 \\
\hline 30 Jan 2006 & B165N3 & North Niger & $16.4 / 15.3$ & $5.9 / 4.7$ & 1.9 & Dust & 7.9 & 2.4 & 1.4 & 0.6 & 0.7 & 19.9 & 4.9 \\
\hline 30 Jan 2006 & B165N4 & North Niger & $14.6 / 13.7$ & $4.0 / 2.9$ & 3.8 & BB1 & 2.5 & 0.6 & 0.9 & $<\mathrm{DL}$ & 1.2 & 7.5 & 1.9 \\
\hline 30 Jan 2006 & $\mathrm{~B} 165 \mathrm{~N} 7$ & North Niger & $13.6 / 13.4$ & $2.8 / 2.8$ & 0.15 & Dust & 37.8 & 18.9 & 7.6 & 4.0 & 1.3 & 103.4 & 23.7 \\
\hline 1 Feb 2006 & B166N1 & Niger/Nigeria & $12.1 / 10.5$ & $3.4 / 5.1$ & 3.3 & BB2 & 7.9 & 3.6 & 2.1 & 1.3 & 2.4 & 21.7 & 5.4 \\
\hline 1 Feb 2006 & $\mathrm{~B} 166 \mathrm{~N} 2$ & Niger/Nigeria & $10.3 / 9.7$ & $5.3 / 6.0$ & 1.5 & Dust & 46.4 & 24.8 & 10.0 & 7.2 & 3.3 & 146.5 & 28.9 \\
\hline 1 Feb 2006 & $\mathrm{~B} 166 \mathrm{~N} 3$ & Niger/Nigeria & $9.7 / 9.7$ & $5.9 / 5.0$ & 1.0 & BB2 & 34.5 & 17.7 & 8.8 & 5.5 & 3.8 & 100.4 & 21.1 \\
\hline 1 Feb 2006 & B166N4 & Niger/Nigeria & $10.1 / 10.1$ & $5.0 / 5.0$ & 0.8 & BB2 & 37.2 & 18.2 & 12.7 & 6.4 & 5.8 & 99.8 & 22.4 \\
\hline 1 Feb 2006 & B166N5 & Niger/Nigeria & $9.8 / 9.9$ & $5.0 / 6.0$ & $0.36-0.42$ & BB2 & 46.2 & 25.5 & 12.8 & 6.7 & 3.7 & 137.0 & 29.6 \\
\hline 1 Feb 2006 & B166N6 & Niger/Nigeria & $9.9 / 9.9$ & $5.8 / 5.0$ & $0.4-0.45$ & BB2 & 39.4 & 25.3 & 14.0 & 6.5 & 4.4 & 121.3 & 25.6 \\
\hline 1 Feb 2006 & B166N7 & Niger/Nigeria & $9.9 / 9.9$ & $5.1 / 6.0$ & 0.42 & BB2 & 39.3 & 27.1 & 12.0 & 6.7 & 1.5 & 124.3 & 25.1 \\
\hline 1 Feb 2006 & B166N8 & Niger/Nigeria & $10.6 / 11.5$ & $5.0 / 3.9$ & 2.7 & $\mathrm{BB} 2$ & 7.9 & 4.7 & 2.0 & 1.3 & 0.9 & 24.6 & 5.1 \\
\hline
\end{tabular}




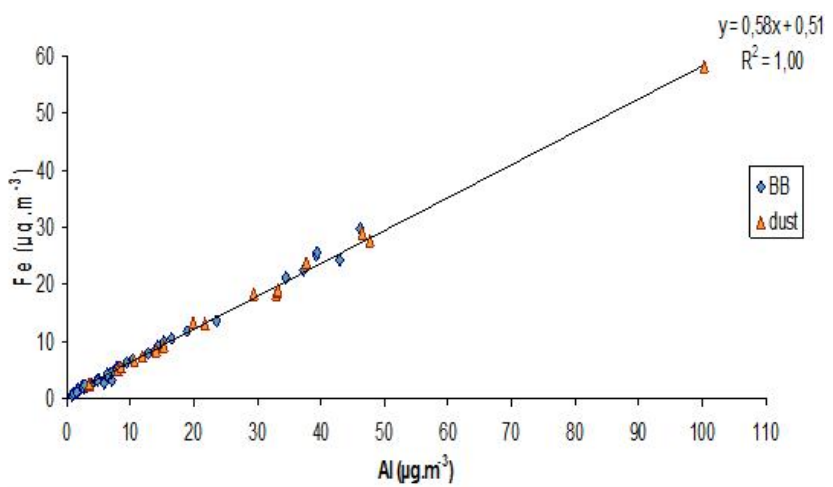

Fig. 1. Total $\mathrm{Fe}$ vs. Total $\mathrm{Al}$ for the entire DUST and $\mathrm{BB}$ aerosol samples.

$2 \mathrm{~km}$ ) and a persistent layer of biomass burning aerosol was observed between 2 and $5 \mathrm{~km}$, often in mixing with dust (Johnson et al., 2008). Based on visual observation and analysis of physical and optical measurements during flights, it was possible to distinguish the aerosol type of each layer (Formenti et al., 2008). Thus every samples collected in dust layers is noted "DUST" and in biomass burning layers is noted "BB" (Table 1). Measurements of OC/OM (Organic Compounds and Organic Matter, respectively) in BB layers show no major anthropogenic fossil fuel pollution sources (Capes et al., 2008).

The total iron concentrations show statistically lower values for samples collected in BB layers $\left([\mathrm{Fe}]_{t o t}=\right.$ $7.8 \pm 8.3 \mu \mathrm{g} \mathrm{m}^{-3}$ ) than samples collected in DUST layers which have concentrations almost twice as large $\left([\mathrm{Fe}]_{\mathrm{tot}}=15.9 \pm 13.4 \mu \mathrm{g} \mathrm{m}^{-3}\right)$. ( $t$-test: $t=2.55$ with $95 \%$ of confidence). The iron concentrations show a very good correlation with $\mathrm{Al}$ whatever the type of samples be (Fig. 1). The ratio $\mathrm{Fe} / \mathrm{Al}$ obtained during this study $(\mathrm{Fe} / \mathrm{Al}=0.58)$ is in agreement with the values obtained at the groundbased site in Banizoumbou (Niger) during the same period $(\mathrm{Fe} / \mathrm{Al}=0.56)$, mainly influenced by dust layer (Chou et al., 2008; Rajot et al., 2008) and in general in the Saharan dust air masses (e.g. Kandler and Schutz, 2007; Lafon et al., 2006). Chemical analysis of individual particles by electronic microscope confirms the very low content of $\mathrm{Fe}$ in the biomass burning particles (mainly constituted of $\mathrm{C}, \mathrm{S}$ and $\mathrm{K}$ ) (Chou et al., 2008; Hand et al., 2010), indicating that even in BB layers, mineral dust is the source of iron, not vegetation combustion. This is consistent with previous observations by Cachier et al., (1995) or Andreae et al., (1998) for African savannah fires. By approximation of the particulate mass on the filters from $\mathrm{Al}$ total content and the mass $\%$ of $\mathrm{Al}$ in the terrestrial crust (8.3\%) (Mason, 1966), the mass \% of various elements has been estimated. The mass $\%$ of the typical elements of terrigeneous origin ( $\mathrm{Al}, \mathrm{Fe}, \mathrm{Si}, \mathrm{Ti}, \mathrm{Ca})$ in DUST and BB samples show that the dust present in the BB samples are chemically similar to the one in DUST samples.

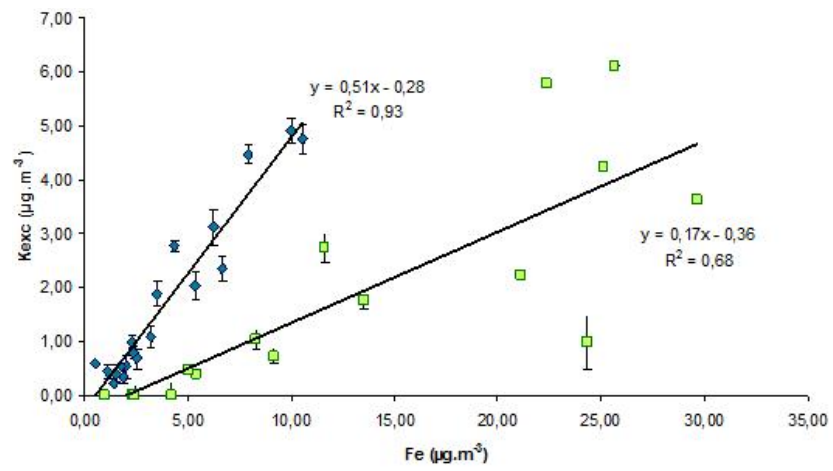

Fig. 2. Plot of Total Fe vs. Kexc in BB samples: two linear relations identified as BB1 group (diamond) and BB2 group (square) are observed.

Potassium is an important species emitted by biomass burning, and the fraction of potassium not related to seasalt and soil dust could be used as a qualitative tracer for biomass combustion (Cachier and Ducret, 1991). Formenti et al. (2008) showed the correlation between $\mathrm{K}$ and $\mathrm{Al}$, for BB samples, confirming the observation of dust and BB mixing on airborne filters. In order to estimate, the contribution of mixing in the samples, the correlation $\mathrm{K} / \mathrm{Fe}$ has been calculated for all DUST samples. A strong linear correlation is obtained and a ratio $\mathrm{K} / \mathrm{Fe}$ in dust is estimated to be $0.31\left(R^{2}=0.99\right)$, based on the slope of the regression curve. From this measurement, the $\mathrm{K}$ which originated from biomass burning has been estimated $\left(\mathrm{K}_{\mathrm{exc}}\right)$ and plotted against the Fe concentration in BB (Fig. 2). There appears to be two kinds of correlation between $\mathrm{K}_{\mathrm{exc}}$ and Fe: (1) $\mathrm{BB}$ samples with a strong linear correlation, $\mathrm{K}_{\mathrm{exc}} / \mathrm{Fe}=0.51$ (noted group BB1), and (2) BB samples where $\mathrm{K}_{\mathrm{exc}}$ exhibits little correlation with $\mathrm{Fe}, \mathrm{K}_{\mathrm{exc}} / \mathrm{Fe}$ is around 0.17 (noted group BB2). Thus, it seems that the samples of the group BB2 are enriched in iron in comparison of group BB1. Assuming mixing of Dust and BB in all samples with $K_{\text {exc }}$, this means a more important contribution from dust in the samples of group BB2. To confirm this large contribution of dust in the group BB2, we estimated the total carbon (TC) on the filters via mass approximation with $\mathrm{Al}$ total content. We found that the average iron $\%$ in the two BB groups and the DUST group of samples are close; $5.5 \%(+/-0.5 \%) ; 5.4 \%$ $(+/-0.4 \%)$ and $5.1 \%(+/-0.3 \%)$ respectively. This corroborates with the iron being mainly issued from dust origin whatever the sample considered. For TC, the average $\%$ are $23.1 \%(+/-14.1 \%)$ for the group BB1 and $12.4 \%(+/-8.4 \%)$ for the group BB2, confirming a lower contribution of BB aerosols in this last group. To explain the two types of correlation between $\mathrm{Fe}$ and $\mathrm{K}$, we may suppose that these two groups are related to 2 processes of mixing between dust and $\mathrm{BB}$ aerosols. It is known that the savannah fires induced an intense remobilisation of terrigeneous particles deposed on the vegetation (Gaudichet et al., 1995). For the group BB1, 
Table 2. Concentrations of dissolved species $\left(\mu \mathrm{g} \mathrm{m}^{-3}\right)$ in the water-soluble fraction of BB and DUST samples. (DL: Detection Limit are calculated as the minimum dissolved mass measured on a filter for a mean sampled air volume of $2 \mathrm{~m}^{3}$ ).

\begin{tabular}{llllllll}
\hline & \multicolumn{3}{c}{ BB } & \multicolumn{3}{c}{ DUST } \\
\hline Element & DL & median & min & $\max$ & median & $\min$ & $\max$ \\
$\mathrm{Al}$ & 0.004 & 0.13 & $<\mathrm{DL}$ & 0.48 & 0.21 & $<\mathrm{DL}$ & 0.95 \\
$\mathrm{Ca}$ & 0.003 & 4.27 & $<\mathrm{DL}$ & 12.52 & 5.21 & 0.45 & 16.79 \\
$\mathrm{Fe}$ & 0.002 & 0.10 & $<\mathrm{DL}$ & 0.43 & 0.07 & 0.01 & 0.55 \\
$\mathrm{~K}$ & 0.026 & 2.16 & $<\mathrm{DL}$ & 4.28 & 0.83 & $<\mathrm{DL}$ & 3.2 \\
$\mathrm{P}$ & 0.1 & 0.16 & $<\mathrm{DL}$ & 0.18 & 0.10 & $<\mathrm{DL}$ & 0.12 \\
$\mathrm{~S}$ & 0.65 & 8.65 & $<\mathrm{DL}$ & 11.94 & 4.11 & $<\mathrm{DL}$ & 10.52 \\
$\mathrm{Si}$ & 0.02 & 0.25 & $<\mathrm{DL}$ & 2.65 & 0.28 & $<\mathrm{DL}$ & 1.05 \\
$\mathrm{SO}_{4}^{2-}$ & 1.9 & 4.12 & $<\mathrm{DL}$ & 5.41 & 2.08 & $<\mathrm{DL}$ & 4.09 \\
$\mathrm{NO}_{3}^{2-}$ & 1 & 4.85 & $<\mathrm{DL}$ & 7.42 & 1.60 & $<\mathrm{DL}$ & 4.54 \\
$\mathrm{C}_{2} \mathrm{O}_{4}^{2-}$ & 0.7 & 1.07 & $<\mathrm{DL}$ & 1.44 & $<\mathrm{DL}$ & & \\
\hline
\end{tabular}

Table 3. Median solubility of major terrigeneous elements in BB and DUST samples.

\begin{tabular}{lll}
\hline Element & BB & DUST \\
\hline $\mathrm{Al}$ & $2.09 \%$ & $0.64 \%$ \\
$\mathrm{Ca}$ & $63.66 \%$ & $40.35 \%$ \\
$\mathrm{Fe}$ & $2.19 \%$ & $0.90 \%$ \\
$\mathrm{~K}$ & $51.03 \%$ & $16.85 \%$ \\
$\mathrm{Mg}$ & $36.80 \%$ & $20.52 \%$ \\
$\mathrm{Ti}$ & $0.54 \%$ & $0.25 \%$ \\
$\mathrm{Si}$ & $0.71 \%$ & $0.00 \%$ \\
\hline
\end{tabular}

as $\mathrm{Fe}$ and $\mathrm{K}_{\mathrm{exc}}$ are correlated, the mixing happened probably directly in the biomass burning air masses due to the dust deposition on vegetation. The value of $\mathrm{K}_{\mathrm{exc}} / \mathrm{Fe}=0.51$ for this group is comparable to the value found by Guieu et al., $(2005)(\mathrm{NSS} \mathrm{K} / \mathrm{Fe}=0.63)$ in Mediterranean region close to sources of summer forest fire. For the group BB2, the large part of iron concentrations could be due to the injection of new dust in the biomass burning air masses during their transport. Moreover, electronic microscope analyses have been carried out on some DUST filters (B160N3, B161N3, B161N5, B165N7) by Chou et al. (2008) and showed a low but systematic occurrence of biomass burning aerosols in external mixing with dust in the samples. Particles imaging on BB filters (B158N6 (BB1), B159N6 and B164N1 (BB2)) showed that dusts are in part internally mixed with soot particles issued from biomass combustion processes (Hand et al., 2010). Consequently, this set of samples (BB2) could represent a crossover between internal aerosols mixing and an addition of dust externally mixed. Another explanation could be related to the evolution of the size distribution of aerosol in the BB air mass during its transport. The dust particles, being coarser than combustion particles, should be removed by gravitational settling involving a decrease of Fe content in the air mass. We studied the number size fraction for different air masses (DUST and BB), measured by PCASP (Osborne et al., 2008). The results show no differences in the distributions. This means either that dust particles are removed in the same order of magnitude than BB particles during transport or that the sampling is too close to the source to determine any difference. If we compare our samples groups BB1 and BB2 to Formenti et al. (2008), there is no correlation with the aged and fresh biomass burning samples, so the first hypothesis should not be the good one.

Finally, it appears that the iron is dust-bearing iron in all the samples and in the case of BB samples, dust are more or less internally mixed with biomass burning aerosols. These two points are critical to the follow-up of the results on the iron solubility values obtained by our experimental protocol. The internal mixing in BB samples, actually, enable us to guess the interaction between BB aerosols species and irondust within atmospheric or seawater, an aqueous phase simulate by our protocol describe previously.

\subsection{Water soluble fraction and iron solubility}

The concentrations have been determined by IC and ICPAES and are shown in Table 2 (Note: We used only the samples that presented results higher than detection limit for iron, $30 \%$ of measurements are not usable, mostly for BB filters, because the results are under the DL). The results show that median concentrations of dissolved $\mathrm{K}, \mathrm{P}, \mathrm{NO}_{3}^{-}, \mathrm{SO}_{4}^{2-}$ and $\mathrm{C}_{2} \mathrm{O}_{4}^{2-}$ are highest in the $\mathrm{BB}$ samples, oxalate being even under limits of detection in all the DUST samples. The concentrations of dissolved $\mathrm{P}, \mathrm{NO}_{3}^{-}, \mathrm{SO}_{4}^{2-}$ and $\mathrm{C}_{2} \mathrm{O}_{4}^{2-}$ present good correlations with those of dissolved $\mathrm{K}\left(R^{2}\right.$ between 0.6 and 0.9 ) as expected, as they are derived from vegetation burning. The $\mathrm{SO}_{4}^{2-} / \mathrm{S}$ ratio of 2.72 is consistent with the value of 3 that would be obtained if the entire measured sulphur was present 


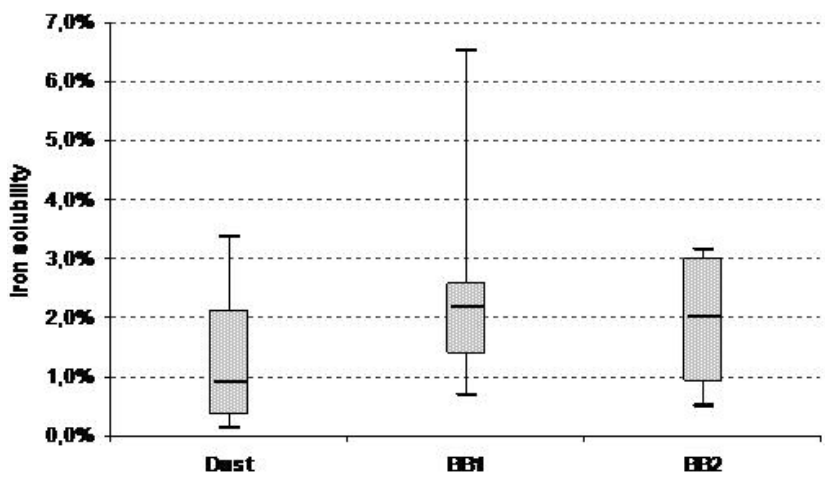

Fig. 3. Boxplot of Percentage solubility estimates of Fe for the 3 kinds of identified samples: DUST (13 Samples), BB1 (8 Samples) and BB2 (4 Samples). Whiskers are from minimum to maximum, box width represents the interquartile range and a stroke is plotted inside of the box to represent the median.

as water-soluble sulphate. It is known that near the emission, elementary $\mathrm{K}$ was mainly present as $\mathrm{KCl}$, evolving to $\mathrm{K}_{2} \mathrm{SO}_{4}$ with the aging of air masses (Gaudichet et al., 1995), due to secondary processing of $\mathrm{SO}_{2}$ from biomass burning sources. This means that the lower the $\mathrm{K} / \mathrm{S}$ ratio the older the $\mathrm{BB}$ air masses. As oxalate has been only determined in biomass burning samples, this indicate that this is the primary source in our samples. Moreover, oxalate concentrations present a negative correlation with $\mathrm{K} / \mathrm{S}$ ratio $\left(R^{2}=0.8\right)$, indicating that the oxalate is formed in the condensation mode during transport.

In term of ocean-atmosphere interaction, $\mathrm{Fe}, \mathrm{N}$ and $\mathrm{P}$ are very important nutrient supplied to the ocean by atmospheric deposition, especially the North tropical Atlantic Ocean (Baker et al., 2003). Water soluble fraction results show that biomass burning aerosols constitute a more important source of dissolved $\mathrm{NO}_{3}^{-}$and $\mathrm{P}$ than dust particles, confirming precedent works (e.g. Baker et al., 2006) (Table 2). Due to the limit of detection of PIXE, we have little information on the contents of particulate $\mathrm{N}$ and $\mathrm{P}$, therefore it is difficult to give further explanations on dissolution process that could be at stake. The discussion should then focus on the estimation of the contribution of mixing particles on the dissolution of iron able to reach the ocean. The median soluble fractions obtained as the ratio of dissolved over total element are presented in Table 3. Typically, the soluble fractions are lower in DUST samples than in BB samples. For elements of terrigeneous origin $(\mathrm{Al}, \mathrm{Fe}, \mathrm{Si}$, and $\mathrm{Ti})$, the median values are always inferior to $3 \%$. The iron soluble fraction $(\mathrm{SFe})$ obtained is detailed in the Fig. 3. We found median soluble fractions of $0.9 \%, 2.0 \%$, and $2.2 \%$ for the group DUST, BB2 and $\mathrm{BB} 1$ respectively.

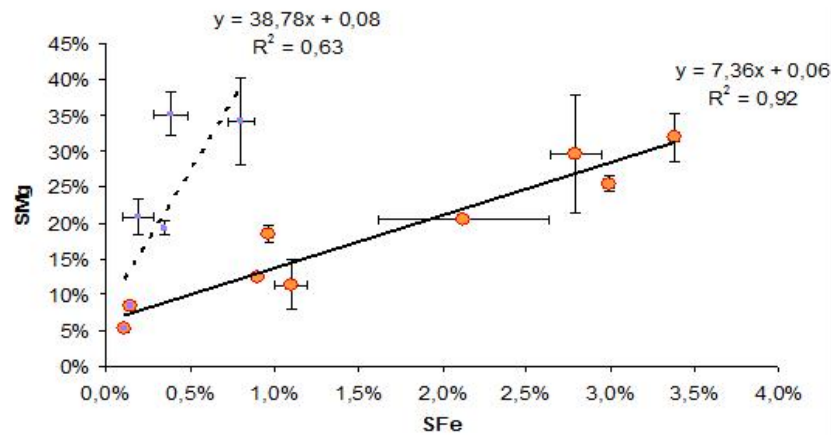

Fig. 4. Plot of percentage of SFe vs. SMg for all DUST samples. The two sets of points highlight the difference of mineralogy in the dust samples, characterized by different ratio. We supposed that the 2 points the closest to the origin belong to both regression equations on the assumption that there is not only one predominant mineral as SFe provider.

\subsubsection{Iron solubility in mineral dust}

It appears that a large variability of the iron soluble fraction in DUST samples, solubility values range from $0.1 \%$ to $3.4 \%$. These values are in good agreement with a number of other estimates for Fe solubility in Saharan dust particles samples collected in the zone of transport over Ocean (e.g. Baker et al., 2006; Bonnet and Guieu, 2004; Johansen et al., 2000). For example, Baker et al. (2006) found Fe solubilities of Saharan dust with values extending from $1.4 \%$ to $4.1 \%$ over the Atlantic Ocean, which is in the same range of value as ours, even if the leaching protocol is a little bit different from ours. As far as we know, no data on the iron solubility exists for location that close to the dust source region in Africa and our results represent the first measurement of the variability of $\mathrm{Fe}$ solubility from mineral dust close to their African sources. To explain this variability, various works considered that the Fe solubility is a function of particle aerosol loading in the atmosphere (Bonnet and Guieu, 2004; Baker et al., 2006). In our case, no relationship between iron solubility and dust concentration (estimated by Al content) was observed, indicating that particle concentration has a small effect on the dust Fe solubility. Moreover, from the measurement of particles size distribution by microscope observation of filters (Chou et al., 2008) and the study of number size fraction of different samples, there appears to be no relationship between particle size and iron solubility (Buck et al., 2010). Recently, Journet et al. (2008) proposed that the role of mineralogical composition was essential to estimate iron solubility. The iron from clays, especially illite and montmorillonite, have a higher solubility for the iron trapped in the crystal lattice of aluminosilicates. Due to the large abundance of clay minerals, it could provide more than $96 \%$ of DFe. Quantitative mineralogical composition of sampled dust is limited by the content of matter on the filter. It was then impossible to establish a relationship 
between the total iron content and SFe. In order to observe a potential effect of mineralogy, we compare the solubility of $\mathrm{Mg}$, as a proxy of the dissolution of clay-containing $\mathrm{Mg}$ such as illite and montmorillonite, and that of Fe (Fig. 4, diamonds). These results emphasize on the fact that a linear relationship exists between soluble fraction of iron and magnesium for several samples, suggesting that the dissolved iron could be issued from the dissolution of clay. Otherwise, the ratio $\mathrm{SMg} / \mathrm{SFe}$ which is around 8 , is in agreement with the ratio for pure illite or montmorillonite, extending from 3 to 8 (Journet et al., 2008). Thus, the variability of iron solubility could be related to the variability of clay content. Besides this correlation, samples (Fig. 4, circles) did not fit with the others. There are a couple of hypotheses to explain the very high $\mathrm{SMg} / \mathrm{SFe}$ ratio measured with these aerosols samples. First of all, the important dissolution of $\mathrm{Mg}$ can be due to the contribution of other clays. For example, pure nontronite presents a ratio of 81 (Journet et al., 2008), a value comparable to the one in this study (around 40). Nevertheless, we cannot set aside the possibility of the presence of other non-Fe mineral containing $\mathrm{Mg}$, which could lead to the increase of the soluble form of this element in the samples. To confirm the role of mineralogical composition of dust, we have carried out the study of back trajectories (http: //ready.arl.noaa.gov/HYSPLIT.php) based on flight plan (Table 1). Calculating back trajectories from each vertical layer within the main dust plume enables us to identify the source regions from where collected air masses were transported. They are very various: from the Southern Algerian, Malian and Mauritanian deserts and also from Chad (Bodélé depression) or North Niger. However, no clear correlation can be found between air masses type and their origin, since air masses can be continuously supply in new dust, from various sources along their atmospheric transport. In order to verify the dust source activation during passage of air masses, we examined a time series of infrared imager SEVIRI dust index images (http://radagast.nerc-essc.ac.uk/Data.htm). It indicates that the only active source, identifiable by remote sensing on the campaign period, was the Bodélé region, with peaks in intensity on 21 January 2006 (B160N3), the 23 January 2006 (B161N5) and also on 30 January 2006 (B165N2). This influence is confirmed by the high content in Si in these samples and by the presence of diatoms by SEM (Scanning Electron Microscope) observations (Washington et al., 2006). These 3 "Bodélé samples" present the lowest iron solubility (around $0.15 \%$ ). Thus, our results seem to emphasize on the relationship between iron solubility/clay content/source and hence partly confirm that the variability of iron solubility in this source region is related to the composition and origin of the aerosols themselves.

\subsubsection{Iron solubility in biomass burning layers}

The soluble iron for BB filters is two times higher than the DUST filters (Fig. 3). These observations are in agreement with the data of Guieu et al., (2005), who observed an increase in iron solubility between dust and biomass burning air masses in Mediterranean region. Chuang et al. (2005) showed that the solubility of Fe produced by anthropogenic emissions of combustion fuel was higher by finding a correlation between BC and SFe. In our case, biomass burning air masses samples present no direct relationship between soluble $\mathrm{Fe}$ and the concentrations in $\mathrm{BC}$, OC or TC, likewise for $\mathrm{K}_{\mathrm{exc}}$. In comparison with dust particles, in this study, biomass burning aerosols are not a significant direct source of soluble iron. Dust remains the major source of Fe even in the biomass burning air masses, and the mixing with combustion particles enables the increase of iron solubility. Besides, it appears that the observed variability on SFe in dust samples is also present for the BB samples, but shifted to higher values (Fig. 3). The presence of organic compounds such as oxalate, or acid species as sulphate could explain the increase of Fe dust solubility in the BB samples, as observed by studies conducted over Atlantic Ocean or in Asian region (Chen and Siefert, 2004). However, these individual compounds exhibit only a little correlation with soluble Fe. It is probable that the large variability observed on iron solubility in dust, explains this little correlation. Desboeufs et al., (2005), showed that the solubility of iron from alumino-silicated matrix is lowest in dust particles than in fly ash issued from combustion process in power plant. The combustion process could also be a determining factor in the increase of solubility observed for the dust mixed with BB, for example by inducing chemical (reductive/oxidant) modifications of iron. It is a known fact that the oxidation state of iron at the surface of particles is highly dependent on the flame conditions (e.g. Jasinski et al., 2005). However, the increase of solubility in BB samples is also observed for the terrigeneous elements which are non-redox active (see above). Consequently, a change in the oxidation state of iron is probably not significant in enhancing iron solubility in mixed samples. The solubility of iron in the BB2, which is enriched in additional dust particles, is yet the same as the solubility obtained in BB1 group. Finally, the results of this study show that the iron in biomass burning air masses is dust-bearing iron and that its solubility is increased in comparison with dust, which had not interacted with BB aerosols. The process explaining the increase of iron solubility from dust in biomass burning air masses is still not well known. Nevertheless, our results show that the solubility of the iron contained within dust is enhanced due to the mixing between dust and BB particles. Besides, the internal mixing between dust particles and biomass burning aerosols in atmospheric water is a main process in term of soluble iron deposition to the surface of open Ocean. 


\section{Conclusion}

In terms of iron deposition, the mineral aerosols are usually considered as dominating combustion sources by a factor above 30 at the global scale (Luo et al., 2008). However, the measurements performed in this study show that the dissolved $\mathrm{Fe}$ concentrations are in the same order of magnitude $\left(\mathrm{DFe}_{B B}=0.13 \mu \mathrm{g} \mathrm{m}^{-3}\right.$ vs. $\left.\mathrm{DFe}_{\text {Dust }}=0.16 \mu \mathrm{g} \mathrm{m}^{-3}\right)$, with the Dust and BB source. More precisely, even though biomass burning in itself is not a direct source of soluble Fe, the entrainment of dust deposited on vegetation makes of, biomass burning a significant indirect source of mineral Fe. Moreover, our results show that the solubility of iron is enhanced by the mixing with biomass burning aerosols. The reasons for this increase are not clear. In particular, we have not been able to link it with the presence of some specific biomass burning species (such as oxalate). Beyond that, the BB air masses could constitute a significant supplier of the nutrients needed by the marine ecosystems. The amount of dissolved Nitrogen and Phosphorous issued from biomass burning aerosols is larger than the one in dust particles samples. Whereas the input of soluble $\mathrm{Fe}$ is dominated by dust deposition, its solubility being enhanced when dust particles are mixed with biomass burning aerosols.

Acknowledgements. Based on a French initiative, AMMA was built by an international scientific group and is currently funded by a large number of agencies, especially from France, the United Kingdom, the United States, and Africa. It has been the beneficiary of a major financial contribution from the European Community's Sixth Framework Research Programme. Detailed information on scientific coordination and funding is available on the AMMA International Web site at www.amma-international.org.

Financial support of the API-AMMA and the LEFE (project BIRD) national programs is acknowledged. The authors also wish to thank the BAe-146 air and ground crews, as well as the FAAM and Met Office observers. H. Cachier and K. Oikonomou (LSCE, Gif sur Yvette, France) provided the analysis of total carbon.

The authors are also grateful to the BAe-146 air and ground crews, as well as the FAAM and Met Office observers, and the AMMASOP0/DABEX PI J. Haywood (Met Office).

They also thank the "Institut National des Sciences de l'Univers" (INSU/CNRS) for his support.

Edited by: C. Reeves

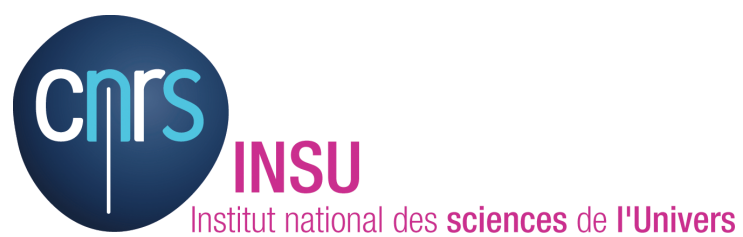

The publication of this article is financed by CNRS-INSU.

\section{References}

Andreae, M. O., Andreae, T. W., Annegarn, H., Beer, J., Cachier, H., Le Canut, P., Elbert, W., Maenhaut, W., Salma, I., Wienhold, F. G., and Zenker, T.: Airborne studies of aerosol emissions from savannah fires in Southern Africa, 2, Aerosol chemical composition. , J. Geophys. Res., 32, 119-128, 1998.

Baker, A. R., Kelly, S. D., Biswas, K. F., Witt, M. and Jickells, T. D.: Atmospheric deposition of nutrients to the Atlantic Ocean, Geophys. Res. Letter, 30(24), 2296, doi:10.1029/2003GL018518, 2003.

Baker, A. R., Jickells, T. D., Witt, M., and Linge, K. L.: Trends in the solubility of iron, aluminium, manganese and phosphorus in aerosol collected over the Atlantic Ocean, Mar. Chem., 98, 4358, 2006.

Bonnet, S. and Guieu, C.: Dissolution of atmospheric iron in seawater, Geophys. Res. Letter, 31, L03303, doi:10.1029/2003GL018423, 2004.

Buck, C. S., Landing, W. M. and Resing, J. A.: Particle size and aerosol iron solubility: A high-resolution analysis of Atlantic aerosols, Mar. Chem., doi:10.1016/j.marchem.2008.11.002, in press, 2010.

Cachier, H.: Isotopic characterization of carbonaceous aerosols, Aeros. Sci. and Tech. 10, 379-385, 1989.

Cachier, H. and Ducret, J.: Influence of biomass burning on equatorial African rains, Nature, 352, 228-230, 1991.

Cachier, H., Liousse, C., and Buat-Menard, P.: Particulate Content of Savannah Fire Emissions, J. Atmos. Chem., 22, 123-148, 1995.

Calzolai, G., Chiari, M., Garcı a Orellana, I., Lucarelli, F., Migliori, A., Nava, S., and Taccetti, F.: The new external beam facility for environmental studies at the Tandetron accelerator of LABEC, Nucl. Instr. \& Meth., B249, 928-931, 2006.

Capes, G., Johnson, B., McFiggans, G., Williams, P. I., Haywood, J., and Coe, H.: Aging of biomass burning aerosols over west Africa: Aircraft measurements of chemical composition, microphysical properties, and emission ratios, J. Geophys. Res.Atmospheres, 113, D00C15, doi:10.1029/2008JD009845, 2008.

Chang, H., Herckes, P., and Collet Jr., J. L.: On the use of anion exchange chromatography for the characterization of water soluble organic carbon. Geophys. Res. Letter, 32, L01810, doi:10.1029/2004GL021322, 2005.

Chen, Y. and Siefert, R. L.: Seasonal and spatial distributions and dry deposition fluxes of atmospheric total and labile iron over the tropical and subtropical North Atlantic Ocean, J. Geophys. Res., 109, D09305, doi:10.1029/2003JD003958, 2004.

Chiari, M., Lucarelli, F., Mazzei, F., Nava, S., Paperetti, L., Prati, P., Valli, G., and Vecchi, R.: Characterization of airborne particulate matter in an industrial district near Florence by PIXE and PESA, J. X-Ray Spectrom., 34(4), 323-329, 2005.

Chou, C., Formenti, P., Maille, M., Ausset, P., Helas, G., Harrison, M., and Osborne, S.: Size distribution, shape, and composition of mineral dust aerosols collected during the African Monsoon Multidisciplinary Analysis Special Observation Period 0 : Dust and Biomass-Burning Experiment field campaign in Niger, January 2006, J. Geophys. Res.-Atmos., 113, D00C10, doi:10.1029/2008JD009897, 2008.

Chuang, P. Y., Duvall, R. M., Shafer, M. M., and Schauer, J. J.: The origin of water soluble particulate iron in the Asian atmospheric outflow, Geophys. Res. Lett., 32, L07813, 
doi:10.1029/2004GL021946., 2005.

Desboeufs, K. V., Losno, R., and Colin, J. L.: Figures of merit of pneumatic and ultrasonic sample introduction systems in inductively coupled plasma-multichannel-based emission spectrometry in an ultra-clean environment, Anal. Bioanal. Chem., 375, 567-573, 2003.

Desboeufs, K. V., Sofikitis, A., Losno, R., Colin, J. L., and Ausset, P.: Dissolution and solubility of trace metals from natural and anthropogenic aerosol particulate matter, Chemosphere, 58, 195-203, 2005.

Formenti, P., Rajot, J. L., Desboeufs, K., Caquineau, S., Chevaillier, S., Nava, S., Gaudichet, A., Journet, E., Triquet, S., Alfaro, S., Chiari, M., Haywood, J., Coe, H., and Highwood, E.: Regional variability of the composition of mineral dust from western Africa: Results from the AMMA SOP0/DABEX and DODO field campaigns, J. Geophys. Res.-Atmos., 113, D00C13, doi:10.1029/2008JD009903, 2008.

Gaudichet, A., Echalar, F., Chatenet, B., Quisefit, J. P., Malingre, G., Cachier, H., Artaxo, P., Maenhaut, W., and Buat-Ménard, P.: Trace elements in tropical African savannah biomass burning aerosol, J. Atmos. Chem., 22, 19-39, 1995.

Guieu, C., Bonnet, S., Wagener, T., and Loye-Pilot, M. D.: Biomass burning as a source of dissolved iron to the open ocean?, Geophys. Res. Lett., 32, L19608, doi:10.1029/2005GL022962, 2005.

Guinot, B., Chachier, H., and Oikonomou, K.: Geochemical perspectives from a new aerosol chemical mass closure, Atmos. Chem. Phys. Discuss., 6, 12021-12055, 2006, http://www.atmos-chem-phys-discuss.net/6/12021/2006/.

Hand, V. L., Capes, G., Vaughan, D. J., Formenti, P., Haywood, J. M., and Coe, H.: Evidence of internal mixing of African dust and biomass burning particles by individual particle analysis using electron beam techniques, J. Geophys. Res., accepted, 2010.

Haywood, J. M., Pelon, J., Formenti, P., Bharmal, N., Brooks, M., Capes, G., Chazette, P., Chou, C., Christopher, S., Coe, H., Cuesta, J., Derimian, Y., Desboeufs, K., Greed, G., Harrison, M., Heese, B., Highwood, E. J., Johnson, B., Mallet, M., Marticorena, B., Marsham, J., Milton, S., Myhre, G., Osborne, S. R., Parker, D. J., Rajot, J. L., Schulz, M., Slingo, A., Tanre, D., and Tulet, P.: Overview of the Dust and Biomass-burning Experiment and African Monsoon Multidisciplinary Analysis Special Observing Period-0, J. Geophys. Res.-Atmospheres, 113, D00C17, doi:10.1029/2008JD010077, 2008.

Ito, A. and Penner, J. E.: Historical emissions of carbonaceous aerosols from biomass and fossil fuel burning for the period 1870-2000, Global Biogeochem. Cy., 19, GB2028, doi:10.1029/2004GB002474, 2005.

Jasinski, J., Pinkerton, K. E., Kennedy, I. M., and Leppert, V. J.: Surface oxidation state of combustion-synthesized [gamma]$\mathrm{Fe}_{2} \mathrm{O}_{3}$ nanoparticles determined by electron energy loss spectroscopy in the transmission electron microscope, Sensors and Actuators B: Chemical, 109, 19-23, 2005.

Johansen, A. M., Siefert, R. L., and Hoffmann, M. R.: Chemical composition of aerosols collected over the tropical North Atlantic Ocean, J. Geophys. Res., 105, 277-215, 2000.

Johnson, B. T., Osborne, S. R., Haywood, J. M., and Harrison, M. A. J.: Aircraft measurements of biomass burning aerosol over West Africa during DABEX, J. Geophys. Res.-Atmospheres, 113, D00C06, doi:10.1029/2007JD009451, 2008.

Journet, E., Desboeufs, K. V., Caquineau, S., and Colin, J. L.: Min- eralogy as a critical factor of dust iron solubility, Geophys. Res. Letter, 35, L07805, doi:10.1029/2007GL031589, 2008.

Kandler, K. and Schutz, L.: Climatology of the average watersoluble volume fraction of atmospheric aerosol, Atmos. Res., 83 , 77-92, 2007.

Kanthale, P., Ashokkumar, M., and Grieser, F.: Somoluminescence, sonochemistry $\left(\mathrm{H}_{2} \mathrm{O}_{2}\right.$ yield) and bubble dynamics: Frequency and power effects, Ultrason. Sonochem., 15, 143-150, 2008.

Kartcikeyan, S. and Balasubramanian, R.: Determination of water soluble inorganic and organic species in atmospheric fine particulates matter, Microchem. J., 82, 49-55, 2006.

Lafon, S., Sokolik, I. N., Rajot, J. L., Caquineau, S., and Gaudichet, A.: Characterization of iron oxides in mineral dust aerosols: Implications for light absorption, J. Geophys. Res., 111, D21207, doi:10.1029/2005JD007016, 2006.

Luo, C., Mahowald, N., Bond, T., Chuang, P. Y., Artaxo, P., Siefert, R., Chen, Y., and Schauer, J.: Combustion iron distribution and deposition, Global Biogeochem. Cycles, 22, GB1012, doi:10.1029/2007GB002964, 2008

Marino, F., Calzolai, G., Caporali, S., Castellano, E., Chiari, M., Lucarelli, F., Maggi, V., Nava, S., Sala, M., and Udisti, R.: PIXE and PIGE techniques for the analysis of Antarctic ice dust and continental sediments, Nucl. Instr. Meth. B, 266, 2396-2400, 2008.

Mason, B. H.: Principles of Geochemistry, John Wiley, New York, USA, 3rd Ed., 329 pp., 1966.

Mills, M. M., Ridame, C., Davey, M., La Roche, J., and Geider, R. J.: Iron and phosphorus co limit nitrogen fixation in the eastern tropical North Atlantic, Nature, 429(6989), 292-294, 2004.

Moore, J. K., Doney, S. C., Glover, D. M., and Fung, I. Y.: Iron cycling and nutrient limitation patterns in surface waters of the World Ocean, Deep Sea Res., Part II, 49(1-3), 463-507, 2002.

Nwofor, O. K., Chineke, T. C., and Pinker, R. T.: Seasonal characteristics of spectral aerosol optical properties at a sub-saharan site, Atmos. Res., 85, 38-51, 2007.

Osborne, S. R., Johnson, B. T., Haywood, J. M., Baran, A. J., Harrison, M. A. J., and McConnell, C. L.: Physical and optical properties of mineral dust aerosol during the Dust and Biomass-burning Experiment, J. Geophys. Res., 113, D00C03, doi:10.1029/2007JD009551, 2008.

Pehkonen, S. O., Siefert, R., Erel, Y., Webb, S., and Hoffmann, M. R.: Photoreduction of iron oxyhydroxides in the presence of important atmospheric organic compounds, Environ. Sci. Technol., 10, 27, 2056-2062, 1993.

Rajot, J. L., Formenti, P., Alfaro, S., Desboeufs, K., Chevaillier, S., Chatenet, B., Gaudichet, A., Journet, E., Marticorena, B., Triquet, S., Maman, A., Mouget, N., and Zakou, A.: AMMA dust experiment: An overview of measurements performed during the dry season special observation period (SOP0) at the Banizoumbou (Niger) supersite, J. Geophys. Res.-Atmospheres, 113, D00C14, doi:10.1029/2008JD009906, 2008.

Sarthou, G., Baker, A. R., Blain, S., Achterberg, E. P., Boye, M., Bowie, A. R., Croot, P., Laan, P., de Baar, H. J. W., Jickells, T. D., and Worsfold, P. J.: Atmospheric iron deposition and sea-surface dissolved iron concentrations in the eastern Atlantic Ocean, Deep Sea Research Part I: Oceanographic Research Papers, 50, 13391352, 2003.

Sofikitis, A. M., Colin, J.-L., Desboeufs, K. V., and Losno, R.: Iron analysis in atmospheric water samples by atomic absorption 
spectroscopy (AAS) in water-methanol., Anal. Bioanal. Chem., 378, 460-464, 2004.

Wang, Y., Zhuang, G., Sun, Y., and An, Z.: Water soluble part of the aerosol in the dust storm season-evidence of the mixing between mineral and pollution aerosols, Atmos. Env., 39, 70207029, 2005.

Washington, R., Todd, M. C., Engelstaedter, S., Mbainayel, S., and Mitchell, F.: Dust and the low-level circulation over the Bodélé Depression, Chad: Observations from BoDEx 2005, J. Geophys. Res., 111(D3), D03201, doi:10.1029/2005JD006502, 2006.
Zhu, X., Prospero, J. M., Savoie, D. L., Millero, F. J., Zika, R. G., and Saltzman, E. S.: Photoreduction of Iron(III) in marine mineral aerosol solutions, J. Geophys. Res., 98(D5), 9039-9046, doi:10.1029/93JD00202, 1993. 